\title{
KOMPETENSI PENYULUH AGAMA ISLAM DALAM MEMELIHARA HARMONI KERUKUNAN UMAT BERAGAMA DI JAKARTA SELATAN
}

\author{
Siti Mukzizatin \\ Badan Litbang dan Diklat Kementerian Agama \\ siti_mukjizatin@ymail.com
}

https://doi.org/10.36052/andragogi.v8i1.113

Diterima: 05 April 2020 | Disetujui: 15 Juni 2020 | Dipublikasikan: 30 Juni 2020

\begin{abstract}
Abstrak
Penelitian ini bertujuan mengetahui Kompetensi Penyuluh Agama Islam dalam memelihara harmoni Kerukunan Umat Beragama di Jakarta Selatan. Penelitian lapangan (Field Research) bersifat eksploratif menggunakan metode deskriptif analitis dengan pendekatan kualitatif. Mengambil lokus di wilayah Jakarta Selatan. Data diambil melalui observasi, wawancara, dokumentasi dan survey dalam bentuk kuisioner kepada penyuluh Agama Islam di wilayah Jakarta Selatan. Data diolah secara deskriptif analisis induktif, yaitu dibangun berdasarkan pada hal-hal khusus dan menuju pada kesimpulan umum. Hasil penelitian menunjukkan: (1) Kompetensi Penyuluh agama Islam di wilayah Jakarta Selatan sudah memiliki persepsi dan pemahaman yang benar dalam membangun wawasan (world view) tentang pluralitas dan multi etnis (multikultur) serta sikap dan kerjasama yang proaktif ketika mengelola konflik dengan mendayagunakan kearifan lokal dan meminimalisir perbedaan. (2) Intoleransi di Jakarta dalam banyak survey menjadi tantangan bagi penyuluh Agama dalam membangun hubungan sosial dengan kelompok binaan, sehingga penafsiran teks-teks keagamaan yang mengarah pada truth claim menganggap diri atau kelompoknya paling benar bisa di minimalisir. (3) Bimbingan dan penyuluhan yang kontinu dan dialog lintas iman secara berkala menjadi modal sosial untuk mencari titik temu dan solusi potensi konflik atau kekerasan antar umat beragama atau internal umat beragama.
\end{abstract}

Kata Kunci: Kompetensi, Bimbingan, Penyuluhan, Kerukunan.

\begin{abstract}
[COMPETENCY OF ISLAMIC RELIGIOUS INSTRUCTORS IN MAINTAINING HARMONY IN RELIGIOUS COMMUNITIES IN SOUTH JAKARTA] This study aims to determine the Competency of Is/amic Religious Instructors in maintaining harmony in Religious Communities in South Jakarta. This studi is a Field research using descriptive analytical methods and qualitative approaches take locus in the South Jakarta area. The Data was collected through interviews and surveys in the form of questionnaires to religious instructors in South Jakarta. The data is processed by inductive analysis, which uses the logic of built based on specific things and leads to general conclusions. The results showed: (1) The competence of Islamic religious instructors in the South Jakarta region already had the right perception and understanding in building insight (world view) on plurality and multi-ethnicity (multicultural) as well as proactive attitudes and cooperation when managing conflicts by utilizing local wisdom and minimizing differences. (2) Intolerance in Jakarta in many surveys becomes a challenge for religious instructors in building social relations with fostered groups, so that the interpretation of religious texts that lead to truth claims considers themselves to be the most correct can be minimized. (3) Continuous guidance and counseling, and periodic interfaith dialogue become social capital to find common ground and solutions for potential conflicts or violence between religious communities or internal religious communities.
\end{abstract}

Keywords: Competency, Guidance, Counseling, Harmony

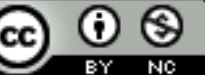

This work is licensed under a Creative Commons Attribution-NonCommercial 4.0 International License 


\section{PENDAHULUAN}

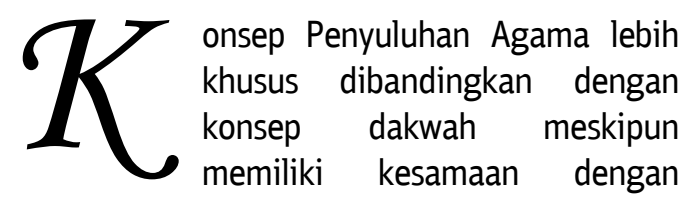
dakwah sebagaimana disampaikan Omar (2004) bahwa ada beberapa istilah yang hampir sama dengan terminologi dakwah diantaranya adalah: Penerangan, pendidikan, Pengajaran dan indoktrinasi.

Dalam dinamikanya, penyuluhan agama dikaitkan juga dengan kegiatan layanan bimbingan atau konseling (counseling), yang bermakna sebagai suatu bentuk hubungan antara klien dengan konselor yang memiliki pengalaman yang cukup memadai bagi pemecahan problema yang berhubungan dengan perkembangan seseorang dan tentang cara untuk memperlancar perkembangan tersebut di satu pihak dan klien dipihak lain yang sedang menghadapi kesulitan, dalam upaya mencapai solusi dan menemukan potensi dirinya ke arah perkembangan yang diinginkan Williamson dalam Arifin (1996). Hal yang sama juga dikemukakan oleh Mubarak (2001) bahwa penyuluhan agama dapat difahami sebagai usaha memberikan bantuan yang bersifat psikologis, mental spiritual, kepada seseorang atau sekelompok orang yang sedang mengalami kesulitan lahir batin dalam kehidupannya, dengan menggunakan metode/pendekatan agama, yakni dengan membangkitkan kekuatan getaran batin (iman) di dalam dirinya agar mampu mengatasi masalah yang dihadapinya.

Kegiatan penyuluhan keagamaan di Indonesia memiliki fungsi yang sangat strategis mengingat bahwa Indonesia adalah "negara beragama" meski bukan "negara agama". Hal ini sesuai dengan sila pertama dari Pancasila "Ketuhanan Yang Maha Esa". Karena itu, agama mendapatkan perhatian serius agar tercipta kedamaian dan ketentraman dan untuk menghindarkan kesalahpahaman ajaran agama, mencegah konflik internal atau antar umat beragama.

Untuk penguatan fungsi penyuluhan agama maka diterbitkanlah Keputusan Presiden Nomor 87 Tahun 1999 tentang Rumpun Jabatan Fungsional PNS yang antara lain menetapkan bahwa penyuluh agama adalah jabatan fungsional pegawai negeri yang termasuk dalam rumpun jabatan keagamaan. Kepres ini kemudian diikuti dengan dikeluarkannya Keputusan Menteri Negara Koordinator Bidang Pengawasan Pembangunan dan Pendayagunaan Aparatur Negara Nomor 54/KEP/MK.WASPAN/ 9/1999 tentang Jabatan Fungsional Penyuluh Agama dan Angka Kreditnya. Dalam Keputusan tersebut, dijelaskan beberapa hal terkait definisi dan tugas penyuluh, rumpun jabatan, kedudukan, dan tugas pokok, bidang dan unsur kegiatan, jenjang jabatan dan pangkat, rincian kegiatan dan unsur yang dinilai dalam angka kredit, penilaian dan penetapan angka kredit.

Dalam operasionalisasinya, penyuluhan agama diperlukan untuk menghadirkan perubahan nyata di masyarakat berbangsa dan bernegara. Tentu perubahan yang dimaksudkan bukan merupakan perubahan semu apalagi perubahan yang dipaksakan sehingga tidak akan berdampak dalam jangka panjang.

Penyuluh Agama mendapatkan perhatian dari pemerintah mengingat fungsi dan tugasnya yang strategis dalam pembangunan bangsa. Penyuluh Agama yang keberadaannya hingga dipelosok tanah air memiliki peran penting dan secara aktif menciptakan suasana batin yang tentram dan rukun hingga akar rumput.

Pelayanan keagamaan menjadi komitmen pemerintah, negara hadir dalam upaya pemenuhan hak dan perlindungan dalam memeluk dan meyakini agama. Oleh karenanya, setiap warga negara mempunyai hak untuk menginternalisasi ajaran agama sesuai dengan keyakinannya.

Tidak dapat dipungkiri ranah agama dan keagamaan seringkali mengalami friksi disebabkan perbedaan paradigma dalam melihat persoalan agama. Dinamika sosial masyarakat merupakan satu helaan nafas dengan kehidupan antar umat beragama, karena secara inheren masyarakat Indonesia menempatkan religiusitas sebagai urusan utama sehingga menyatu dengan kehidupan sosial.

Secara faktual Indonesia sebagai bangsa yang majemuk baik dari etnis, suku, bahasa dan stratifikasi sosial jika tidak dikelola dengan baik berpotensi menjadi hal yang destruktif. Konflik 
yang terjadi menunjukkan betapa pemahaman agama menjadi salah satu penyebab munculnya konflik. Agama yang idealnya menjadi perekat sosial nyatanya menjadi bagian faktor pemicu konflik. Peristiwa kerusuhan yang terkait SARA hingga kini masih menjadi Ancaman dan bahaya latent.

Jakarta sebagai ibukota memiliki masyarakat yang heterogen dan tingkat keragaman yang tinggi, didalamnya berdiam berbagai suku, agama, ras, etnis, bahasa dan budaya. Sebagai ibukota Negara menjadi etalase toleransi kehidupan antar masyarakat, namun dilapangan masih banyak ditemui aksiaksi intoleran akibat dari pengaruh pilkada dan pilpres dan ditenggarai kurangnya peran pemerintah daerah.

Setara Institute merilis, hasil penelitian yang sangat mengejutkan, mengukur praktek toleransi di 94 kota Indonesia tahun 2018 dengan judul "Jakarta Masih Masuk dalam 10 Kota dengan Nilai Toleransi Rendah". hasil penelitian ini, terdapat empat aspek yang diukur, yaitu regulasi pemerintah kota, tindakan pemerintah, regulasi sosial, dan demografi agama (http://setarainstitute.org/indeks-kota-toleran-tahun2017).

Atas dasar fenomena di atas, kerukunan antar umat beragama dan intern umat beragama menjadi pilar penting untuk memelihara harmoni kehidupan keagamaan dan Penyuluh Agama sebagai "perpanjangan tangan negara" mempunyai tanggung jawab untuk mengokohkan persatuan dalam bingkai kebhinekaan. Fenomena ini sangat menarik untuk di teliti agar mendapatkan gambaran tentang kompetensi penyuluh Agama di DKI Jakarta dalam menginternalisasikan kerukunan Umat untuk memelihara harmoni kehidupan keagamaan.

Ruang lingkup penelitian adalah wilayah Jakarta Selatan dengan pertimbangan bahwa heterogenitas masyarakat Jakarta Selatan sebagai miniatur Jakarta, semua suku bangsa, agama, kepercayaan, budaya, kelas sosial ekonomi dan keragaman latar pendidkan dan mata pencahariannya. Hubungan antar umat beragama terkadang mengalami ketegangan dan potensial terjadi disharmoni. Selanjutnya, permasalahan dalam penelitian ini mempunyai beberapa karakter, berkontribusi signifikan, serta dapat didukung dengan data empiris, serta sesuai dengan kemampuan dan keinginan penulis.

Berdasarkan permasalahan tersebut, perlu dilakukan penelitian mengenai Kompetensi Penyuluh Agama sebagai ujung tombak dalam membangun kesadaran harmoni masyarakat di wilayah Jakarta Selatan. Judul penelitian “Kompetensi Penyuluh Agama Islam Dalam Memelihara Kerukunan Umat Beragama di Jakarta Selatan". Penelitian ini akan mengeksplorasi Materi dan metode Penyuluhan yang berkaitan dengan Kerukunan Umat Beragama dan Pelaksanaan bimbingan dan Penyuluhan di wilayah Binaan Penyuluh agama di Jakarta Selatan.

Penelitian ini dibatasi pada bagaimana kompetensi penyuluh Agama dalam memelihara harmoni Kerukunan umat beragama, materi dan metode penyuluhan yang berkaitan dengan kerukunan umat beragama dan upaya bimbingan dan penyuluhan Agama dalam penguatan toleransi antar dan intern umat untuk merekatkan Kerukunan Umat Beragama?

Penelitian ini bertujuan untuk mengetahui kompetensi penyuluh Agama Islam di Jakarta Selatan dalam memperkuat harmoni kehidupan keagamaan dan pelayanan Keagamaan yang berkeadilan dan merata tentang Kerukunan Umat Beragama yang berkaitan dengan isu intoleransi di DKI Jakarta.

\section{Kajian Teoretis}

\section{Fungsi dan Peran Penyuluh Agama}

Sebagaimana dipaparkan oleh Misra ada empat hal yang harus diwujudkan dalam setiap Penyuluhan pembangunan adalah : Menghargai sesama secara manusiawi, Bebas dari tirani, dan Kehidupan masyarakat yang memiliki "sense of belonging" yang tinggi. Hampir serupa, Todaro (diacu dalam Ndraha), menyebutkan terjadinya suatu pembangunan bila mampu memenuhi kebutuhan dasar (life sustenance), menjadi manusia (self-esteem), dan memiliki (freedom from servitude). Berdasarkan hal tersebut dapat disimpulkan bahwa pembangunan selain harus mewujudkan ketersediaan fisik juga menyiapkan mental manusianya agar menjadi manusia seutuhnya (Misra, 1991). 
Konsep dakwah memiliki cakupan dan dimensi yang lebih luas bila dibandingkan dengan konsep penyuluhan agama. Hal ini bisa kita telusuri mulai dari pengertian dakwah menurut bahasa yang berarti ajakan, seruan, panggilan, undangan (0mar, 2004). Maupun secara istilah, di mana dakwah menurut Hasyimi (1994) adalah mengajak umat untuk meyakini dan mengamalkan akidah dan syariah Islam yang terlebih dahulu diyakini dan diamalkan oleh pendakwah itu sendiri. Menurut Amin (2008), dakwah adalah aktivitas yang dilakukan secara sadar dan sistematis dalam rangka menyampaikan pesan-pesan agama Islam dan menjalankannya dengan baik, dalam kehidupan individual maupun masyarakat untuk mencapai kebahagiaan manusia baik di dunia maupun di akhirat dengan menggunakan berbagai media dan metode tertentu.

Dalam konteks keagamaan, penyuluhan agama dilakukan oleh berbagai agama yang dianut di Indonesia, di mana juru penerangsuatu agama memberikan penerangan kepada umatnya yang membutuhkan bimbingan hidup agar sesuai dengan tujuan dari agama yang dianutnya tersebut. Dalam agama Kristen dikenal dengan nama missi dan zending, dalam agama Buddha disebut menebar kabajikan dan lain sebagainya.

Agama sebagai "guidance" pemeluknya untuk dapat hidup berdampingan secara mutualisme menjadi satu tarikan nafas dengan dinamika sosial kemasyarakatan dalam kehidupan antar umat beragama karena penduduk Indonesia menempatkan relegiusitas sebagai urusan utama sehingga menyatu dengan kehidupan sosial. Sebagaimana Firman Allah dalam Q.S. Ali Imran/3:104.

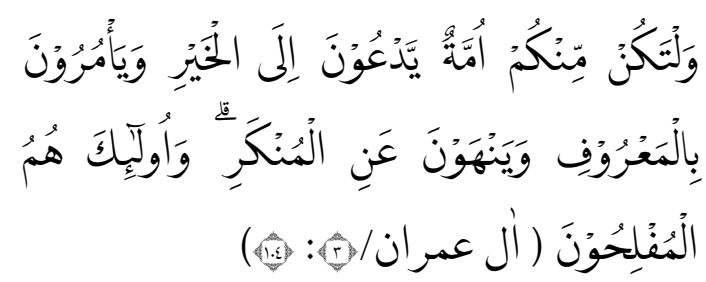

"Dan hendaklah di antara kamu ada segolongan orang yang menyeru kepada kebajikan, menyuruh (berbuat) yang makruf, dan mencegah dari yang mungkar. Dan mereka itulah orang-orang yang beruntung"
Ranah Agama dan keberagamaan menjadi instrumen penting menyangkut kemaslahatan berbangsa dan bernegara baik dibidang sosial, ekonomi, budaya, bahkan ranah politik. Meskipun tidak dapat dipungkiri seringkali mengalami kontroversi karena perbedaan paradigma dalam melihat persoalan agama. Sebagaimana Firman Allah dalam Q.S. AnNahl/16: 125:

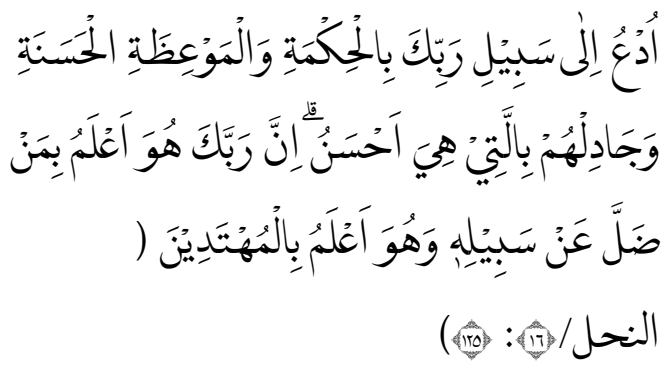

"Serulah (manusia) kepada jalan Tuhanmu dengan hikmah dan pengajaran yang baik, dan berdebatlah dengan mereka dengan cara yang baik. Sesungguhnya Tuhanmu, Dialah yang lebih mengetahui siapa yang sesat dari jalanNya dan Dialah yang lebih mengetahui siapa yang mendapat petunjuk"

Masyarakat yang masih menjunjung tinggi norma dan tradisi (kearifan lokal) disinyalir mempunyai tingkat kohesi yang tinggi. Schmitt menjelaskan kohesi sosial dipandang sebagai karakter masyarakat dalam kaitannya dengan hubungan antara individu, kelompok, dan lembaga-lembaga asosiasi dan proses pengembangan masyarakat yang sedang berlangsung nilai-nilai bersama, tantangan bersama dan kesempatan yang setara dalam masyarakat berdasarkan sikap percaya, harapan dan interaksi timbal balik di antara masyarakat.

Dalam penjelasannya lebih lanjut Schmitt mengatakan kohesi sosial dipandang sebagai karakter masyarakat yang berkaitan dengan hubungan antara unit-unit sosial seperti individu, kelompok, dan lembaga-lembaga asosiasi, selain itu kohesi sosial bermakna proses pengembangan masyarakat yang sedang berlangsung meliputi nilai-nilai kebersamaan, tantangan dan kesempatan yang setara dalam masyarakat berdasarkan sikap percaya, harapan di antara masyarakat (Schmitt, 2002).

Dalam tulisan ini akan diuraikan terlebih dahulu istilah-istilah yang berhubungan dengan judul penelitian mengenai: "Kompetensi 
Penyuluh Agama Islam Dalam Memelihara Harmoni Kerukunan Umat Beragama di Jakarta Selatan".

Kompetensi merupakan suatu konsep yang berhubungan dengan pekerjaan seseorang. Sekurangnya ada dua kelompok definisi terkait kompetensi ini. Pertama, bahwa kompetensi dibangun dari karakteristik seseorang yang dipersiapkan untuk menjalankan pekerjaan (baik tugas maupun tuntutan profesi) secara efektif, dan efisien sehingga tolok ukurnya berupa kesiapan kerja seseorang menjadi unsur yang dominan. Hal ini sebagaimana disampaikan oleh Spencer \& Spencer (1993), Imran dan Ganang (1999) diacu dalam Winaryanto, Sahirul, \& Yunasaf (2011) maupun Culp, McKee, \& Nestor (2007).

Kedua, memberikan penekanan khusus bahwa kompetensi terdiri dari perpaduan berbagai unsur seperti karakteristik personal, pengetahuan, sikap dan keterampilan yang sangat dibutuhkan seseorang dalam melakukan pekerjaannya. definisi kedua ini didukung oleh Klausmeier \& Goodwin (1966), Stone dan Beiber (1997), Cooper \& Graham (2001), Wisher diacu dalam Kurniawan dan Jahi (2005), Lucia dan Lepsinger 1999 diacu dalam Marius et al.(2007), D.W. Sue dan Davis Sue 2008 diacu dalam Minami (2009), Namdar, Rada, \& Karamidehkordi (2010).

Kompetensi seseorang menurut Spencer \& Spencer (1993) memiliki lima karakteristik, yaitu : Motives, Traits, Self concept, Knowledge, dan Skill. Dari ke lima aspek tersebut, pengetahuan (knowledge) dan keterampilan (skill) sifatnya dapat dilihat (visible) dan mudah dikembangkan. Sedangkan konsep diri (self concept), watak (traits) dan motif (motives) sifatnya tidak tampak (hidden) dan lebih sulit untuk dikembangkan.

Brewerton (2004) diacu dalam Rutherford (2004) menjelaskan seseorang tidak hanya menggunakan satu buah kompetensi dalam satu kurun waktu, namun dapat menggunakan beragam kompetensi secara serempak yang merupakan kombinasi antara kompetensi khusus dan kompetensi kunci. Menurutnya, kompetensi terbagi dalam dua kelompok besar, yaitu Specific competencies (kompetensi khusus) dan Key competencies (kompetensi kunci).
Kompetensi menurut Suhendra adalah "suatu kegiatan yang berkesinambungan, dinamis, secara sinergis mendorong keterlibatan semua potensi yang ada secara evolutif dengan keterlibatan semua potensi" (Suhendra, 2006). Kompetensi dapat didefinisikan sebagai pengetahuan, sikap, keterampilan, karakteristik pribadi yang sangat penting guna mencapai keberhasilan dalam suatu pekerjaan. Kompetensi adalah merupakan suatu sifat yang dihubungkan dengan kriteria efektivitas atau kinerja yang sangat baik dalam suatu pekerjaan (Spencer \& Spencer, 1993). Spencer (1993) menyatakan bahwa kompetensi merupakan karakter dan selamanya ada pada kepribadian seseorang dan dapat diprediksi tingkah laku dan performance pada semua situasi dan job tasks. Hal ini diperkuat oleh Bergerhenegouwen dan Marshall yang menyatakan bahwa kompetensi merupakan hal yang paling sulit ditiru, dikarenakan karakteristiknya yang memang berbeda dan spesifik bagi masing-masing individu. Dengan demikian, dapat dinyatakan bahwa kompetensi Penyuluh Agama merupakan cerminan kepribadian seseorang baik berupa sikap, pengetahuan dan keterampilan yang dimiliki sehingga dapat memprediksikan kinerja atau performanya.

Dengan demikian, konsep dasar kompetensi adalah kemampuan individu yang terdiri dari pengetahuan, keterampilan, sikap, motivasi, pendidikan, bidang keahlian dan pengalaman yang dipersiapkan untuk menghadapi pekerjaannya secara efektif dan efisien.

Beberapa definisi terkait penyuluh disebutkan dalam perundang-undangan. Sebagaimana dalam peraturan menteri sosial No. 10 tahun 2014 tentang penyuluhan sosial, definisi penyuluh sosial adalah seseorang yang mempunyai tanggung jawab dan wewenang untuk melaksanakan kegiatan penyuluhan sosial bidang penyelenggaraan kesejahteraan sosial. Dalam Peraturan Menpan RB No. 3 Tahun 2014 tentang Jabatan Fungsional Penyuluh hukum dan angka kreditnya definisi penyuluh Hukum adalah Pegawai Negeri Sipil (PNS) yang diberi tugas, tanggung jawab, wewenang, dan hak secara penuh untuk melakukan kegiatan penyuluhan hukum. 
Undang-Undang No. 16 Tahun 2006 Tentang Sistem Penyuluhan Pertanian, Perikanan dan Kehutanan menyebutkan bahwa penyuluh pertanian, perikanan dan kehutanan adalah pegawai negeri sipil yang selanjutnya disebut penyuluh yang diberi tugas, tanggung jawab, wewenang, dan hak secara penuh oleh pejabat yang berwenang pada satuan organisasi lingkup pertanian, perikanan, atau kehutanan untuk melakukan kegiatan penyuluhan. Keputusan Menkowasbangpan No. 54 tahun 1999 tentang Jabatan Fungsional Penyuluh Agama dan Angka Kreditnya, Penyuluh Agama adalah Penyuluh Agama Fungsional dan Penyuluh Agama honorer. Penyuluh Agama Fungsional merupakan Pegawai Negeri Sipil yang diberi tugas, tanggungjawab, wewenang dan hak secara penuh oleh pejabat yang berwenang untuk melaksanakan bimbingan atau penyuluhan agama dan pembangunan kepada masyarakat melalui bahasa agama.

Dari beberapa definisi tersebut nampak jelas seluruh penyuluh memiliki bidang khusus sebagai bidang garapannya, kecuali penyuluh agama yang umum. Kekhususannya hanya dibatasi pada pendekatannya saja dalam memberikan penyuluhan yaitu menggunakan bahasa agama. Ini jelas di satu sisi menguntungkan karena dapat bertugas di berbagai bidang, namun di sisi lain memberatkan akibat ketidakjelasan dari konsep maupun operasionalisasinya. Hal mana hanya bisa diatasi dengan perincian tugas selengkaplengkapnya dalam peraturan di bawahnya (misalnya peraturan menteri dan seterusnya).

Sebagai bentuk peran formal, penyuluh agama fungsional dibagi menjadi 2 (tiga) klasifikasi, yaitu: penyuluh agama terampil (pengangkatan dengan latar belakang pendidikan setara diploma) dan penyuluh agama ahli (pengangkatan dengan latar belakang pendidikan setara sarjana). Sebagaimana keputusan Menkowasbangpan No. 54 tahun 1999 tentang Jabatan Fungsional Penyuluh Agama dan Angka Kreditnya (pasal 6), penyuluh agama terampil terbagi menjadi 3 jenis, yaitu ;

1. Penyuluh agama pelaksana,

2. Penyuluh agama pelaksana lanjutan, dan

3. Penyuluh agama penyelia.
Dalam pasal yang sama disebutkan bahwa penyuluh agama ahli terbagi menjadi 3 jenis, yaitu:

1. Penyuluh agama muda,

2. Penyuluh agama madya, dan

3. Penyuluh agama utama.

Pengklasifikasian pada penyuluh agama fungsional ini ditujukan untuk memberikan arah orientasi pembinaan dan cakupan sasaran penyuluhan.Tujuan akhirnya agar dapat diwujudkan pembinaan yang holistik dan terarah kepada masyarakat.

Penyuluh Agama adalah merupakan Pegawai Negeri Sipil yang berkedudukan pada instansi pemerintah, dalam hal ini Kementerian Agama, dengan tugas pokok melaksanakan bimbingan penyuluhan keagamaan dan pembangunan melalui bahasa agama kepada masyarakat.

Harmoni adalah keselarasan. Dalam beberapa bahasa,harmoni disebut armonía (Spanyol \& Italia), harmonie (Perancis dan Jerman), zusammenklang (Jerman). Dalam kamus besar bahasa indonesia harmoni merupakan kesamaan rasa, aksi, gagasan dan minat; selaras; dan serasi (Asry, Hakim, Ruhana, \& Khalikin, 2013).

Istilah "kerukunan" dalam Kamus Besar Bahasa Indonesia yang diterbitkan oleh Departemen Pendidikan dan Kebudayaan, diartikan sebagai "hidup bersama dalam masyarakat dengan "kesatuan hati" dan "bersepakat" untuk tidak melakukan perselisihan dan pertengkaran". Kerukunan adalah istilah yang bermakna "baik" dan "damai". Intinya, hidup bersama dalam masyarakat dengan "kesatuan hati" dan "bersepakat" untuk tidak menciptakan perselisihan dan pertengkaran.

Dalam pasal 1 angka (1) peraturan bersama Menteri Agama dan Menteri Dalam No. 9 dan 8 Tahun 2006 tentang Pedoman Pelaksanaan tugas Kepala Daerah/ Wakil Kepala Daerah dalam pemeliharaan kerukunan umat beragama, pemberdayaan forum kerukunan umat beragama, dan pendirian rumah ibadat dinyatakan bahwa: Kerukunan umat beragama adalah hubungan sesama umat beragama yang dilandasi toleransi, saling pengertian, saling menghormati, menghargai kesetaraan dalam pengamalan ajaran agamanya dan kerjasama 
dalam kehidupan bermasyarakat, berbangsa dan bernegara berdasarkan Pancasila dan Undang-Undang Dasar Negara Republik Indonesia Tahun 1945. Mencermati pengertian kerukunan umat beragama, tampaknya peraturan bersama di atas mengingatkan kepada bangsa Indonesia bahwa kondisi ideal kerukunan umat beragama, bukan hanya tercapainya suasana batin yang penuh toleransi antar umat beragama, tetapi yang lebih utama adalah bagaimana bisa saling bekerjasama.

Kerukunan Umat Beragama merupakan kondisi dimana antar umat beragama dapat saling menerima, saling menghormati keyakinan masing-masing, saling tolong menolong, dan bekerjasama dalam mencapai tujuan bersama. Hal ini, mengingatkan bahwa kondisi ideal kerukunan umat beragama, bukan hanya tercapainya suasana batin yang penuh toleransi antar umat beragama, tetapi yang lebih penting adalah bagaimana mereka bisa saling bekerjasama. Kerukunan bukan hanya berlaku dalam dunia pergaulan. Namun Kerukunan antar umat beragama adalah cara untuk mempertemukan, mengatur hubungan antara orang yang tidak seagama atau antara golongan umat beragama dalam kehidupan sosial kemasyarakatan.

\section{Operasional Tugas dan Fungsi Penyuluh Agama}

Dalam operasionalisasinya, penyuluhan agama diperlukan untuk menghadirkan perubahan nyata di masyarakat berbangsa dan bernegara. Tentu perubahan yang dimaksudkan bukan merupakan perubahan semu apalagi perubahan yang dipaksakan sehingga tidak akan berdampak dalam jangka panjang. Selain itu perlu kiranya mewujudkan mental manusia yang memanusiakan manusia, menghargai potensi pengembangan diri, mampu bekerjasama, mandiri, dan berkelanjutan menuju masyarakat sejahtera lahir dan bathin.

Kegiatan bimbingan dan penyuluhan isemakin tumbuh subur dalam masyarakat sehingga timbul badan-badan atau organisasi pembinaan rohani baik secara struktural resmi maupun tidak resmi yang kemudian dikenal dengan nama Binroh, Babinrohis, Bintal, Rawatan Rohani dan sebagainya. Dengan demikian, semakin meluaslah kegiatan penyuluhan ini bukan hanya terhadap pembinaan umat Islam saja, namun meluas kepada umat agama yang lain. Kegiatan pembinaan rohani ini kemudian meningkat kepada pembinaan karyawan dan keluarganya yang diselenggarakan baik di kantor-kantor maupun komplek-komplek perumahan, di rumah-rumah para pejabat, di pendopo maupun tempat lainnya. (Departemen Agama Kantor Wilayah Jawa Barat 2009). Kini kegiatan penyuluhan sudah menjadi kebutuhan bagi masyarakat, terutama untuk meningkatkan pengamalan agama yang bersentuhan langsung dengan aktifitas hidup sehari-hari.

Dengan demikian, tugas penyuluh agama bukan semata-mata melaksanakan penyuluhan agama dalam arti sempit berupa pengajian, akan tetapi seluruh kegiatan penerangan baik berupa bimbingan maupun penerangan berbagai program pembangunan. Tugas pokok bimbingan dan penyuluhan sesungguhnya memiliki keterkaitan erat dengan peran penyuluh agama di masyarakat dengan kompetensi yang diharapkan sesuai kebutuhan kelayan.

Adapun fungsi penyuluh agama di antaranya meliputi membimbing umat dalam menjalankan ajaran agama, menyampaikan gagasan-gagasan pembangunan kepada masyarakat dengan bahasa agama, serta meningkatkan kehidupan umat beragama (Departemen Agama Kantor Wilayah Provinsi Jawa Barat, 2009b). Secara ringkas dapat dikemukakan bahwa fungsi penyuluh agama selama ini diarahkan untuk peningkatan kualitas internal umat beragama, menjadi penyambung suara pemerintah kepada masyarakat di bidang keagamaan dan secara eksternal ikut berkontribusi dalam menjaga kerukunan umat beragama.

Peran penyuluh agama dalam prakteknya tidaklah bersifat tunggal yaitu hanya sebagai motivator pembangunan, namun juga meluas ke berbagai peran strategis lainnya. Pada awalnya peran penyuluh sebagai penerang bagi masyarakat, namun seiring kebutuhan, berkembang antaranya sebagai; analis, advisor, advokator, dan inovator (Santopolo \& Gallaher, 1967).

Lebih kompleks lagi kontribusi pembangunan mengharuskan penyuluh agama 
untuk dapat berperan sebagai perencana program (dari sebagai manajer program sampai ke tahapan evaluasinya (Swanson, Bentz, \& Sofranko, 1997), fasilitator dan pendidik (Ife, 2002), Agen perubahan, perantara, pendidik, tenaga ahli, perencana sosial, advokat dan sebagai aktivis (Adi, 2003), sebagai fasilitor, pendidik, utusan, teknikal (Nasdian, 2003), katalis, pemberi solusi, penolong proses dan penghubung sumberdaya (Valera, Martinez, \& Plopino, 1987) pengembangan kebutuhan sebagai agen perubahan bertugas untuk menggerakkan masyarakat melakukan perubahan dan membina hubungan dengan masyarakat sasaran binaan (Lippitt, Watson, \& Westley, 1958), serta berbagai peran lainnya baik yang berkaitan dengan administrasi, konten, program, sumber daya maupun berkaitan dengan kelayan.

Melaksanakan penyuluhan agama merupakan salah satu tugas pokok penyuluh agama. Dalam hal ini penyuluh agama memberikan layanan penyuluhan tatap muka kepada kelompok binaannya baik kelompok binaan masyarakat umum maupun kelompok binaan khusus yang telah menjadi kelompok binaan tetapnya.Tugas yang lainnya yaitu memberikan bimbingan konsultasi baik teknis maupun non teknis kepada personal dan organisasional.

\section{Penelitian Terdahulu yang Relevan}

Lembaga Ilmu Pengetahuan Indonesia (LIPI) melalui Kedeputian Bidang IImu Pengetahuan Sosial dan Kemanusiaan (IPSK) selama tahun 2018 melakukan penelitian tentang intoleransi dan radikalisme di sembilan provinsi di Indonesia. Temuan tersebut menunjukkan intoleransi terhadap kelompok agama dan etnik yang berbeda lebih banyak terjadi dalam kehidupan politik dalam kehidupan sehari-hari. Sebagai contoh adalah penggunaan isu-isu keagamaan dalam kontestasi politik di sejumlah daerah. Survey dilakukan untuk mengukur bagaimana identifikasi agama dan etnik berpengaruh terhadap intoleransi dan radikalisme dengan menggunakan beberapa variabel, seperti perasaan terancam, fanatisme keagamaan, ketidakpercayaan, penggunaan media sosial, tingkat sekularisasi, dan status sosial dan latar belakang ekonomi.

Hasil Survei Wahid Foundation menemukan sejumlah data yang dinilai cukup mengkhawatirkan. Dari total 1.520 responden, sebanyak 59,9 persen memiliki kelompok yang dibenci, responden adalah umat Islam berusia di atas 17 tahun atau sudah menikah dan survey menggunakan metode random sampling dengan margin error sebesar 2,6 persen dan tingkat keyakinan 95 persen. Kelompok yang dibenci meliputi mereka yang berlatarbelakang agama non muslim, kelompok tionghoa, komunis, dan lainnya. Sebanyak 7,7 persen yang bersedia melakukan tindakan radikal bila ada kesempatan dan sebanyak 0,4 persen justru pernah melakukan tindakan radikal. Penyebab terjadinya intoleransi dan radikalisme di tubuh umat Islam Indonesia selain ideologi ialah alienasi dalam sektor sosial dan ekonomi.

Setara Institute bekerjasama dengan UKPPIP atas 94 kota, 10 kota mendapatkan skor toleransi terendah, yaitu DKI Jakarta dengan skor 2,30, Banda Aceh 2,90, Bogor 3,05, Cilegon 3,20, Depok 3,30, Yogyakarta 3,40, Banjarmasin 3,55, Makassar 3,65, Padang 3,75, dan Mataram 3,78. Berdasarkan kajian yang menilai enam parameter, yakni Rencana Pembangunan Jangka Menengah Daerah (RPJMD), kebijakan diskriminatif, tindakan nyata pemerintah kota, pernyataan pemerintah kota, peristiwa pelanggaran kebebasan beragama atau berkeyakinan, dan demografi penduduk berdasarkan agama tahun 2010, DKI Jakarta berada diposisi paling buncit dengan skor 2,30 dari angka tertinggi 7. DKI Jakarta mendapatkan skor toleransi terendah karena sepanjang November 2016 sampai Oktober 2017 setidaknya ada 14 peristiwa yang berhubungan dengan pelanggaran kebebasan beragama dan berkeyakinan yang terjadi di lbu Kota. DKI turun dari peringkat 65 dalam IKT tahun 2015, menjadi peringkat 94 atau skor terendah pada IKT tahun 2017, hal itu disebabkan penguatan intoleransi dan politisasi identitas keagamaan. Penduduk Jakarta juga diberikan image menjadi penduduk intoleran karena relasi sosial yang buruk.

Memperbaiki relasi sosial untuk memelihara harmoni dan masalah toleransi menjadi pekerjaan rumah terutama bagi Penyuluh 
agama terkait dengan tugas dan fungsinya memberikan penguatan kerukunan kehidupan keagamaan dan layanan keagamaan yang adil dan merata.

\section{METODE PENELITIAN}

Penelitian ini bersifat eksploratif dan deskriptif analitis dengan pendekatan kualitatif. Menurut Bogdan dan Taylor (1975), pendekatan kualitatif merupakan prosedur penelitian yang menghasilkan data deskriptif berupa kata-kata tertulis atau lisan dari orangorang dan prilaku yang dapat diamati (Moleong, 1991). Analisis data yang digunakan dalam penelitian ini adalah logika induktif, yaitu menggunakan logika berpikir di mana silogisme dibangun berdasarkan pada hal-hal khusus atau data di lapangan dan bermuara pada kesimpulan umum (Bungin, 2011). Prosedur penelitian ini dilaksanakan untuk memperoleh gambaran tentang kompetensi penyuluh Agama di wilayah Jakarta Selatan dalam memelihara harmoni kerukunan umat. Secara spesifik penelitian ini akan menelaah beberapa variabel pada kompetensi penyuluh Agama Islam dalam bimbingan dan penyuluhan untuk penguatan dan internalisasi toleransi antar dan intern umat beragama dalam merekatkan Kerukunan Umat Beragama terkait dengan isu intoleran masyarakat DKI Jakarta. penelitian ini dimaksudkan untuk memahami fenomena yang terjadi pada subjek penelitian dengan cara mendeskripsikan kompetensi Penyuluh Agama dalam salah satu tugas dan Fungsinya memelihara harmoni dan mencegah sikap intoleran sehingga diharapkan tercipta kondisi ideal kerukunan umat beragama.

Dalam melihat fenomena intoleransi dan potensi disharmoni di wilayah Jakarta Selatan, penelitian ini menggunakan teori Kohesi sosial yang memiliki dua dimensi cakupan yaitu: Dimensi pertama; ketidaksetaraan yang berupa praktik diskriminasi berdasarkan Ras, gender, umur, strata sosial, etnis, disabilitas dan kebangsaan. Eksklusi sosial juga termasuk didalamnya, hal ini dapat berupa kemiskinan (eksklusi dari partisipasi bidang ekonomi), marginalisasi sosial (eksklusi dari patisipasi kegiatan sosial atau organisasi sosial). Dimensi Kedua; modal sosial yang fokus pada penguatan hubungan sosial, interaksi, relasi, kearifan lokal dan aspek lain yang dikategorikan sebagai modal sosial dalam masyarakat (Heyneman, 2005).

Sumber penelitian berupa sumber data primer dan sumber data sekunder. Sumber data primer, merupakan hasil observasi, in-depth interview, Angket/survey, dokumentasi dari Pokjaluh DKI Jakarta dan materi penyuluhan terkait dengan kerukunan Umat Beragama. Informan pada komunitas Penyuluh PNS yang terdiri dari; Penyuluh Pertama, Penyuluh Muda, Penyuluh Madya, Ketua Pokjaluh dan institusi pembina di Kanwil Kementerian Agama DKI Jakarta. Adapun sumber data sekunder menggunakan beberapa buku, jurnal dan majalah serta berita-berita yang ada di surat kabar yang terkait dengan isu yang akan diteliti.

Studi Dokumentasi dilakukan di awal saat proses dan pasca pengumpulan data lapangan sebagai pengayaan bagi temuan lapangan. Perubahan selama ada di lapangan sangat dimungkinkan selaras dengan perkembangan permasalahan yang terjadi.

Pengumpulan Data berfokus pada "persepsi", "sikap" dan "kerjasama", dijelaskan melalui beberapa indikator yaitu Toleransi, Kesetaraan dan kerjasama yang dirumuskan melalui item-item pertanyaan dalam kuesioner. Penggunaan kuesioner sebagai instrumen dalam mengumpulkan data tentang kohesi sosial dan modal sosial (Social Capital) serta modal manusianya (Human Capital). Data akan diklasifikasi ke dalam tiga variabel, yang kemudian dirinci ke dalam iten-item pertanyaan. Masing-masing variabel ini kemudian diurutkan secara rangking ke dalam lima tingkatan, yaitu dari yang paling tidak rukun sampai pada yang harmonis. Teknik pengumpulan data yang dilakukan adalah:

\section{a. Observasi}

Observasi dilakukan untuk mengamati secara langsung kegiatan Bimbingan dan Penyuluhan serta kesesuaiannya dengan materi tentang kerukunan beragama dan interaksi antara Penyuluh dengan masyarakat binaan. Observasi ini diarahkan untuk memahami setting Religious Social engineering serta kondisi sosial masyarakatnya. Begitu juga dengan memahami kondisi sosiologis masyarakat yang beragam yang terjadi $\mathrm{di}$ 
tengah-tengah masyarakat, serta memahami kemungkinan-kemungkinan terjadinya konflik sosial yang bisa jadi disebabkan oleh pemahaman teologis yang berbeda dan implikasi-implikasinya dalam konteks penyuluhan agama di masyarakat.

\section{b. Wawancara}

wawancara mendalam (in-depth interview) Untuk mendapatkan informasi dari informan. Teknik wawancara tak terstruktur merupakan teknik wawancara yang dipilih dalam penelitian ini. Teknik pengumpulan data dengan wawancara tak terstruktur, menurut Deddy Mulyana (2002), wawancara tak terstruktur memungkinkan informan dapat mendefinisikan diri dan lingkungannya dengan menggunakan istilah-istilahnya sendiri tentu saja berdasarkan struktur sosial dan pemahaman keagamaan dan keragaman latar. Model ini relevan dengan penelitian yang dilaksanakan.

\section{c. Survey}

Survey/angket dilakukan dengan metode Purposive Sampling, ditentukan kelayakan yang menjadi sampel, agar objektif ditentukan berdasar populasi jumlah penyuluh dan sebaran penduduk. Diharapkan dengan metode ini akan diperoleh akurasi data.

\section{d. Dokumentasi}

Melengkapi berbagai teknik diatas, studi dokumentasi diperlukan terutama untuk memperkaya landasan-landasan teoretis dan eksplorasi data masa lalu yang berkaitan dengan tema dalam penelitian ini. Yaitu, pengumpulan data berdasarkan dokumen tertulis berupa materi penyuluhan, regulasi atau kebijakan tertentu. Kaitannya dengan fokus penelitian ini, metode dokumentasi digunakan untuk mengungkapkan data tentang implementasi pembinaan dan bimbingan penyuluhan dan implikasinya terhadap interaksi masyarakat di DKI Jakarta.

Prosedur analisis data yang digunakan dalam penelitian ini adalah mengacu pada prosedur analisis data Miles \& Hubermen, (1992). Menurut Milles dan Hubermen, analisis data dalam penelitian kualitatif, secara umum dimulai sejak pengumpulan data, reduksi data, penyajian data, dan penarikan kesimpulan atau verifikasi. Dalam prosedur ini sekaligus mencerminkan komponen-komponen analisis yang bersifat interaktif. Kegiatan analisis selama pengumpulan data dimaksud, untuk menetapkan fokus di lapangan, menyusun temuan sementara, pembuatan rencana pengumpulan data berikutnya, pengembangan pernyataan-pernyataan analitis dan penetapan sasaran-sasaran data berikutnya. Kemudian dari pengumpulan data (data collection) tersebut, direduksi (data reduction) sebagai upaya pemilihan pemusatan perhatian pada penyederhanaan, dan mendiskripsikan datadata lapangan.

Dalam proses reduksi data, dilakukan pemilihan atau pemetaan dengan membuat kategori-kategori berdasarkan permasalahan yang diteliti. Langkah selanjutnya menyajikan informasi atau data yang disusun untuk penarikan kesimpulan. Kesimpulan-kesimpulan juga di verifikasi selama kegiatan penelitian berlangsung di lapangan, sehingga akan jelas bagaimana karakteristik data tersebut secara valid.

Persepsi, sikap dan kerjasama tiga dimensi ini dilakukan pembobotan, mulai dari yang paling rendah sampai yang paling tinggi. Responden diminta untuk memilih salah satu dari 4 jawaban. Jawaban tersebut diberi nomor secara berurut mulai dari no.1 sampai no.4. keempat jawaban yang ada tentu saja tidak memperlihatkan arti apa-apa bagi responden selain bahwa mereka diminta untuk memilih satu saja jawaban yang dirasa sesuai dengan pandangan, pendapat dan persepsi mereka.

Penomoran jawaban tersebut sekaligus memberikan bobot, yang mengindikasikan potensi kerukunan pada diri para responden. Ketiga dimensi di atas bisa menggambarkan kecenderungan-kecenderungan dalam kaitannya dengan kerukunan hidup beragama. "Persepsi" dalam hal ini berkaitan dengan penilaian pemeluk suatu agama terhadap pemeluk agama lainnya dalam berbagai segi kehidupan sosial mereka. Persepsi ini disamping dipengaruhi oleh unsur-unsur yang bersifat normatif, seperti pemahaman agama, juga dipengaruhi oleh event-event sosial yang mengelilingi kehidupan mereka. Sementara itu "sikap" dan "kerjasama" adalah unsur-unsur yang berkaitan dengan tindakan sosial masyarakat beragama. Ketiganya dijadikan 
sebagai indikator kerukunan, yaitu toleransi, solidaritas dan kerjasama.

Selain ketiga dimensi kerukunan di atas, survei ini juga mengidentifikasi identitas responden, ari sisi pengetahuan yang dimiliki responden. Variable lainnya berkaitan dengan pengetahuan responden tentang hal-hal yang berkaitan dengan kehidupan antarumat beragama. Selain itu, juga mengeksplor pengetahuan tentang pemahaman ajaran agama responden dalam hal hubungan mereka dengan umat yang berasal dari agama lain.

Dengan cara ini diharapkan bisa tergambar pola hubungan. Hubungan yang dimaksud berkaitan dengan tingkat keintiman (intimacy) atau bahkan sebaliknya kebencian yang menyertainya. Dengan kata lain, kerukunan hubungan antarumat beragama ini akan diukur melalui seberapa jauh para pemeluk agama menentukan jarak sosial mereka terhadap para pemeluk agama lainnya. Apakah hubungan antar pemeluk agama tersebut berjalan normal dalam artian tidak disertai adanya prejudice atau bahkan kebencian atau sikap lainnya yang bisa memunculkan ketegangan atau bahkan konflik. Dalam bahasa yang lebih sederhana, penelitian survei ini melihat sejauhmana keharmonisan menyertai hubungan mereka.

\section{TEMUAN DAN PEMBAHASAN}

\section{Temuan}

a. Profil Kementerian Agama Kota Jakarta Selatan

Jakarta Selatan terletak pada 106'22'42

Bujur Timur (BT) s.d. 106'58'18 BT, dan 5'19'12 Lintang Selatan (LS). Luas Wilayah sesuai dengan Keputusan Gubernur KDKI Nomor 1815 tahun 1989 adalah 145,37 km2 atau $22,41 \%$ dari luas DKI Jakarta. Terbagi menjadi 10 kecamatan dan 65 kelurahan, berada di belahan selatan banjir kanal, dengan batas wilayah sebagai berikut:

- Sebelah Utara: Banjir Kanal Jl. Jend. Sudirman Kec. Tanah Abang, Jl. Kebayoran lama dan Kebun Jeruk.

- Sebelah Timur: Kali Ciliwung

- Sebelah Selatan: Berbatasan dengan kota Administrasi Depok dan Kota Tangerang

- Sebelah Barat: Berbatasan dengan Kecamatan Ciledug, Kota Administrasi Tangerang
Topografi Wilayah Jakarta Selatan pada umumnya dapat dikategorikan sebagai daerah perbukitan rendah dengan tingkat kemiringan $0,25 \%$. Ketinggian tanah rata-rata mencapai 550 meter di atas permukaan laut. Pada wilayah bagian selatan, banjir kanal relatif merupakan daerah perbukitan jika dibandingkan dengan wilayah bagian utara.

Kota Jakarta Selatan terdiri dari 10 kecamatan dengan jumlah penduduk 2.141.941 jiwa, yang terdiri dari 1.077.327 jiwa dengan jenis kelamin laki-laki dan 1.064.614 jiwa perempuan.

Jumlah penduduk terpadat berada di Kecamatan Jagakarsa dengan jumlah penduduk 345.176 jiwa dan yang terjarang adalah Kecamatan Setiabudi dengan jumlah penduduk 134.936 jiwa.

Tabel 1. Jumlah Penduduk menurut Pemeluk Agama

\begin{tabular}{lrr}
\hline \multicolumn{1}{c}{ Agama } & \multicolumn{1}{c}{ Jumlah } & \multicolumn{1}{c}{$\%$} \\
\hline Islam & 1.763 .888 & 83.25 \\
Katholik & 140.083 & 6.54 \\
Protestan & 127.231 & 5.94 \\
Budha & 28.488 & 1.33 \\
Hindu & 82.251 & 3.84 \\
\hline Jumlah & 2.141 .941 & 100.00 \\
\hline
\end{tabular}

Data pegawai yang ada di lingkungan Kantor Kementerian Agama Kota Jakarta Selatan berdasarkan Jabatan Struktural dan Fungsional sebagaimana disajikan dalam Tabel 2.

Tabel 2. Data Pegawai Kementerian Agama Kota Jakarta Selatan

\begin{tabular}{lr}
\hline \multicolumn{1}{c}{ Jabatan } & Jumlah \\
\hline Pejabat Struktural & 22 \\
Jabatan Fungsional Tertentu & \\
- Guru & 1.567 \\
- Arsiparis & 1 \\
- Pengawas & 36 \\
- Analis Kepegawaian & 1 \\
- Penyuluh Agama & 41 \\
- Penghulu & 46 \\
- Pengelola Pengadaan Barang/ Jasa & 4 \\
Jabatan Fungsional Umum & 407 \\
\hline \multicolumn{2}{c}{ Jumlah }
\end{tabular}

b. Tugas dan Fungsi Kementerian Agama Kota Jakarta Selatan

Kantor Kementerian Agama mempunyai tugas melaksanakan tugas dan fungsi Kementerian Agama dalam wilayah 
kabupaten/kota berdasarkan kebijakan Kepala Kantor Wilayah Kementerian Agama provinsi dan ketentuan peraturan perundang-undangan.

Tabel 3. Data Penyuluh Agama Islam PNS Kementerian Agama Kota Jakarta Selatan

\begin{tabular}{lrrrrr}
\hline \multirow{2}{*}{ Kecamatan } & Jml & \multicolumn{2}{c}{ Pendidikan } & \multicolumn{3}{c}{ Jenis } \\
\cline { 3 - 6 } & & S1/S2 & SLTA & L & P \\
\hline $\begin{array}{l}\text { Kebayoran } \\
\text { Baru }\end{array}$ & 4 & 4 & - & 4 & - \\
$\begin{array}{l}\text { Kebayoran } \\
\text { Lama }\end{array}$ & 5 & 5 & - & 2 & 3 \\
Setia Budi & 5 & 3 & - & 1 & 2 \\
Mampang & 2 & 2 & - & 1 & 1 \\
Tebet & 4 & 4 & - & 2 & 2 \\
Cilandak & 6 & 6 & - & 1 & 5 \\
Pasar Minggu & 2 & 2 & - & 2 & - \\
Pancoran & 5 & 5 & - & 4 & 1 \\
Pesanggrahan & 6 & 5 & 1 & 2 & 4 \\
Jagakarsa & 5 & 5 & 0 & 2 & 4 \\
\hline \multicolumn{1}{c}{ Jumlah } & 43 & 42 & 1 & 24 & 19 \\
\hline
\end{tabular}

Tabel 4. Data Penyuluh Agama Islam PNS dan Non PNS/Honorer Kota Jakarta Selatan

\begin{tabular}{|c|c|c|}
\hline \multirow{2}{*}{ Kecamatan } & \multicolumn{2}{|c|}{ Penyuluh } \\
\hline & PNS & Honorer \\
\hline Tebet & 4 & 18 \\
\hline Mampang Prapatan & 2 & 18 \\
\hline Pasar Minggu & 2 & 18 \\
\hline Kebayoran Baru & 4 & 18 \\
\hline Kebayoran Lama & 5 & 18 \\
\hline Setiabudi & 3 & 18 \\
\hline Cilandak & 6 & 18 \\
\hline Pancoran & 5 & 18 \\
\hline Jagakarsa & 5 & 18 \\
\hline Pesanggrahan & 6 & 18 \\
\hline Jumlah & 43 & 180 \\
\hline
\end{tabular}

Tabel 5. Data Lembaga Keagamaan dan Yayasan Islam Kota Jakarta Selatan

\begin{tabular}{lrrrrr}
\hline \multirow{2}{*}{ Kecamatan } & \multicolumn{5}{c}{ Jenis Lembaga } \\
\cline { 2 - 6 } & MT & TPQ & Ol & PA & YI \\
\hline Tebet & 195 & 85 & 4 & 1 & 10 \\
Mampang & 223 & 64 & 9 & 22 & 24 \\
Prapatan & & & & & \\
Pasar Minggu & 238 & 113 & 7 & 22 & 33 \\
Kebayoran Baru & 43 & 55 & 5 & - & 11 \\
Kebayoran Lama & 259 & 77 & 16 & - & 54 \\
Setiabudi & 102 & 50 & 13 & 6 & 17 \\
Cilandak & 154 & 76 & 10 & 4 & 24 \\
Pancoran & 91 & 70 & 12 & 4 & 23 \\
Jagakarsa & 325 & 138 & 16 & 1 & 29 \\
Pesanggrahan & 180 & 75 & 4 & 4 & 13 \\
\hline \multicolumn{1}{c}{ Jumlah } & 1810 & 803 & 96 & 44 & 248 \\
\hline \multicolumn{7}{l}{ Keterangan: } & & & & & \\
$\quad$ MT : Majelis Taklim & &
\end{tabular}

$$
\begin{array}{ll}
\text { Ol } & \text { : } \text { Ormas Islam } \\
\text { PA } & \text { : Panti Asuhan } \\
\text { YI } & \text { : Yayasan Islam }
\end{array}
$$

\section{Pembahasan}

Puslitbang Bimas Agama Dan Layanan Keagamaan Badan Litbang melakukan survei nasional Kerukunan Umat Beragama tahun 2019 dengan 3 indikator sebagai instrumen pengukuran yaitu Toleransi, Kesetaraan dan kerjasama. Survei dilakukan di 33 Provinsi menunjukkan bahwa Indeks rata-rata nasional tahun 2019 sebesar 73,83 rentang skor 0-100. Angka itu terdiri dari tiga indikator, yaitu indikator toleransi dengan skor 72,37, kesetaraan 73,72, dan kerja sama 75,40. . Angka ini meningkat jika dibanding hasil perolehan tahun lalu yaitu 70,90 tapi masih rendah jika dibanding perolehan indeks tahun 2015 yaitu 75,36.

Kementerian Agama mencatat skor Indeks Kerukunan Umat Beragama (KUB) DKI Jakarta hanya 71,3, di bawah rata-rata nasional 73,83. Dengan angka itu Jakarta berada di urutan ke27 dalam pemeringkatan Indeks KUB. Selain DKI, Kemenag menyebut ada 17 provinsi lainnya yang memiliki skor Indeks KUB di bawah rata-rata. Mereka adalah Jawa Timur 73,7, Kalimantan Timur 73,6, Gorontalo 73,2, Kepulauan Bangka Belitung 73,1, dan Lampung 73,1 .

Kerukunan Umat Beragama di Jakarta berada di bawah indeks rata-rata nasional, meskipun hasil survei ini masih bisa dikritisi namun setidaknya Jakarta sebagai Barometer Nasional menjadi perhatian kita bersama. Kompetensi penyuluh agama sangat dibutuhkan untuk berkontribusi menginternalisasikan harmoni dan relasi antar umat beragama.

Kompetensi Penyuluh sangat dipengaruhi oleh jam terbang, nilai-nilai yang diyakini serta konsep diri yang bersumber dari ajaran agama, sehingga menjadi faktor dominan.

Persepsi dalam hal ini berkaitan dengan perspektif penyuluh terhadap kondisi Jakarta dan dinamikanya sebagai kota yang majemuk, multikultur dan plural sehingga potensi menjadi kota yang kapanpun bisa mengalami konflik terbuka antar umat dan golongan meskipun pemicunya karena politisasi agama atau ujaran kebencian. Dalam dimensi ini Penilaian pemeluk suatu agama terhadap pemeluk agama lainnya 
dipengaruhi oleh unsur-unsur yang bersifat normatif, seperti ajaran agama dan Konsep memahami keberagamaan dalam kehidupan sosial.

Sikap menunjukkan pendirian yang diperlihatkan oleh para penyuluh baik itu terhadap penyampaian materi, relasi sosial ataupun respon terhadap pemeluk agama laiinnya. Aspek ini menggambarkan apa yang dilakukan berupa tindakan nyata penyuluh agama terhadap fakta sosial dan problem sosial yang sangat komplek di wilayah binaannya. Dalam penelitian ini yang sikap diungkapkan melalui pernyataan-pernyataan.

Kerjasama adalah toleransi yang bersifat aktif, terutama pada aspek hubungan sosial penyuluh agama pada pola relasi antara pemeluk agama yang berbeda. Jadi kalau persepsi lebih pada tindakan kedalam yang belum nyata sedangkan kerjasama adalah realitas hubungan sosial.

Hasil survei yang dilakukan kepada penyuluh agama di wilayah Kantor Kementerian Agama Jakarta Selatan dikategorikan dalam 4 aspek yaitu:

\section{a. Aspek Kompetensi Penyuluh tentang} Kerukunan Umat Beragama

1) Masa Kerja menjadi Penyuluh Agama

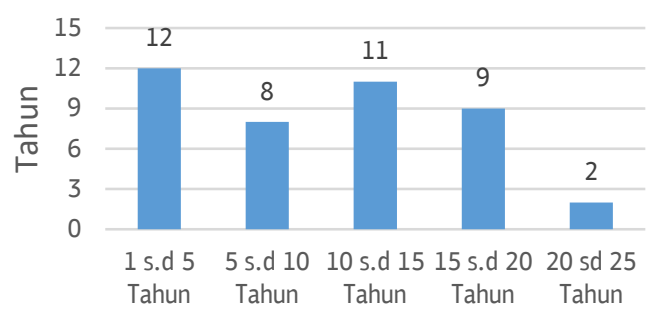

Grafik 1. Masa Kerja Penyuluh

2) Pelayanan Bimbingan dan Penyuluh di Wilayah Binaan

a) Menentukan metode penyuluhan langkah pertama yang harus dilakukan dengan memilih metode dan media yang tepat

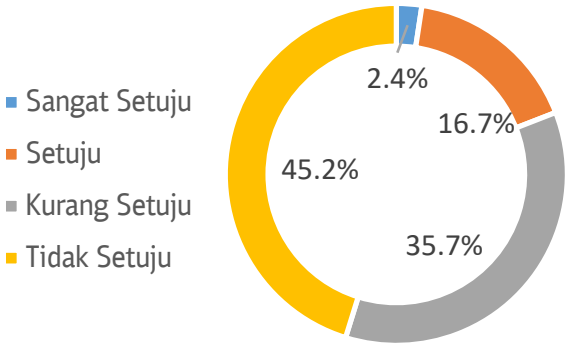

Grafik 2. Respon terhadap 2)a) b) Kerukunan Umat Beragama (KUB) menjadi salah satu materi penyuluhan, namun masih ada konflik terbuka antar umat. Hal ini disebabkan pasifnya penyuluh memberikan bimbingan dan penyuluhan

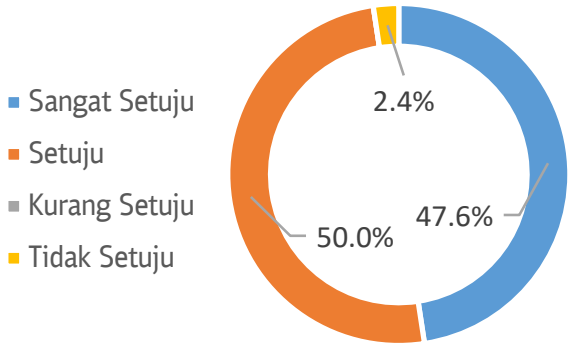

Grafik 3. Respon terhadap 2) b)

c) Pelayanan keagamaan menjadi komitmen pemerintah, namun negara hadir setengah hati dalam upaya pemenuhan hak dan perlindungan dalam memeluk dan meyakini agama

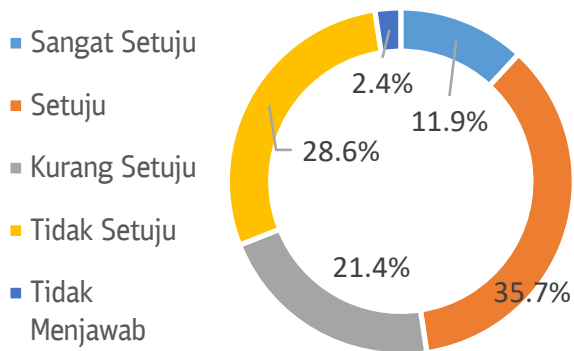

Grafik 4. Respon terhadap 2) c)

3) Mengelola Konflik

Apakah ada kebijakan / peraturan pemerintah tentang Pendirian Rumah Ibadah

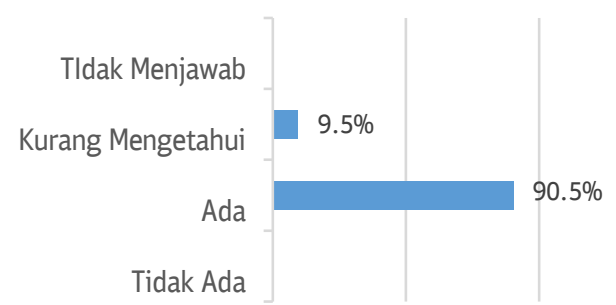

Grafik 5. Respon terhadap 3)

Catatan tentang Karakteristik Responden:

- Sebaran Responden Penyuluh Agama Bukan Hanya PNS namun Penyuluh Non PNS masuk dalam Cakupan Survei karena kedua kategori tersebut bersama-sama mempunyai tanggung jawab untuk 
menginternalisasikan relasi harmonis Kerukunan Umat Beragama. Namun dalam penelitian ini hanya di fokuskan pada penyuluh PNS.

b. Aspek Persepsi

1) Jakarta berpotensi menjadi kota yang rentan pada konflik terbuka antar umat berbeda agama.

a) Jakarta berpotensi menjadi kota yang mengalami konflik terbuka antarumat berbeda agama

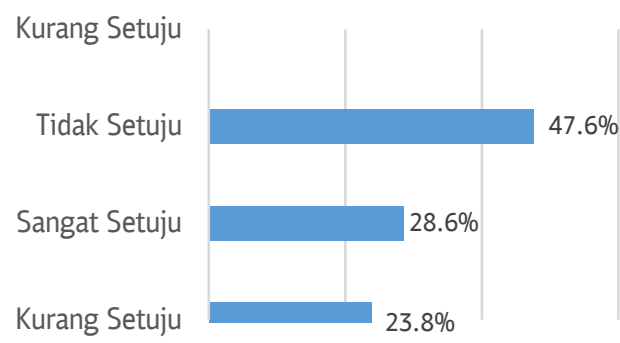

Grafik 6. Respon terhadap 1) a)

b) Jakarta sebagai Ibukota menggambarkan pluralitas dari segi suku, etnis dan budaya, problem toleransi sangat krusial

Grafik 7. Respon terhadap 1) b)

- Sangat Setuju

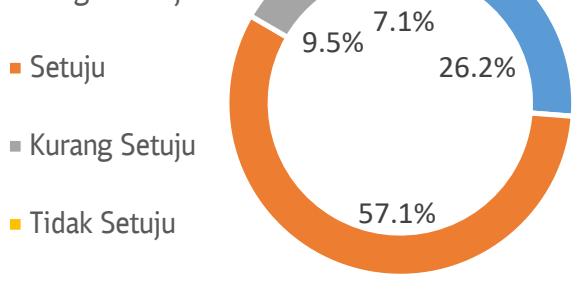

c) Apakah di wilayah (provinsi) tempat anda tinggal pernah ada konflik terbuka antar umat berbeda agama

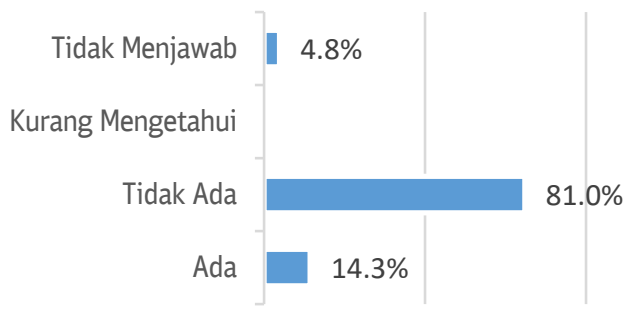

Grafik 8. Respon terhadap 1) c)

2) Jakarta menjadi kota intoleran, hal ini disebabkan oleh politisasi agama dan ujaran kebencian a) Jakarta menjadi kota intoleran yang disebabkan oleh politisasi agama dan ujaran kebencian

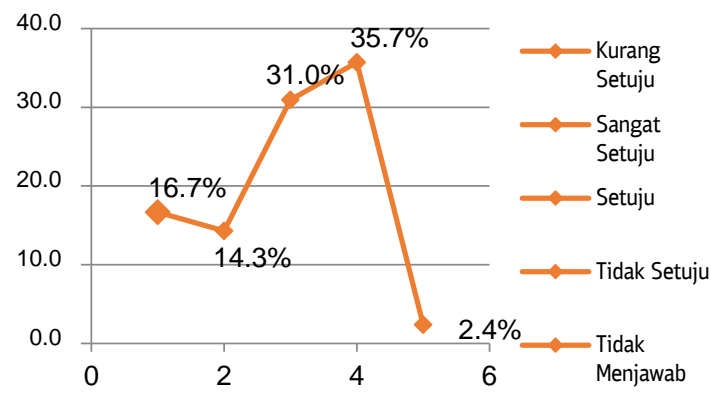

Grafik 9. Respon terhadap 2) a)

b) Kebijakan / Peraturan Pemerintah tentang Pendirian Rumah Ibadah sudah tersosialisasi dengan baik

- Sangat Setuju

- Setuju

- Kurang Setuju

- Tidak Setuju

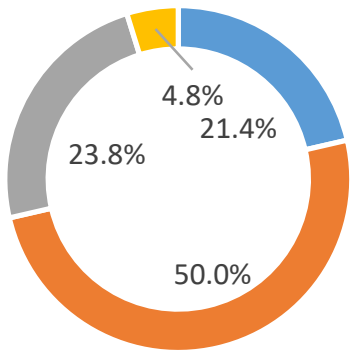

Grafik 10. Respon terhadap 2) b)

3) Bagaimana hubungan antar umat beragama di wilayah anda

a) Kekuatan nilai-nilai agama tereduksi oleh politik sesaat dan kepentingan ini merobek rajutan kerukunan umat di Jakarta

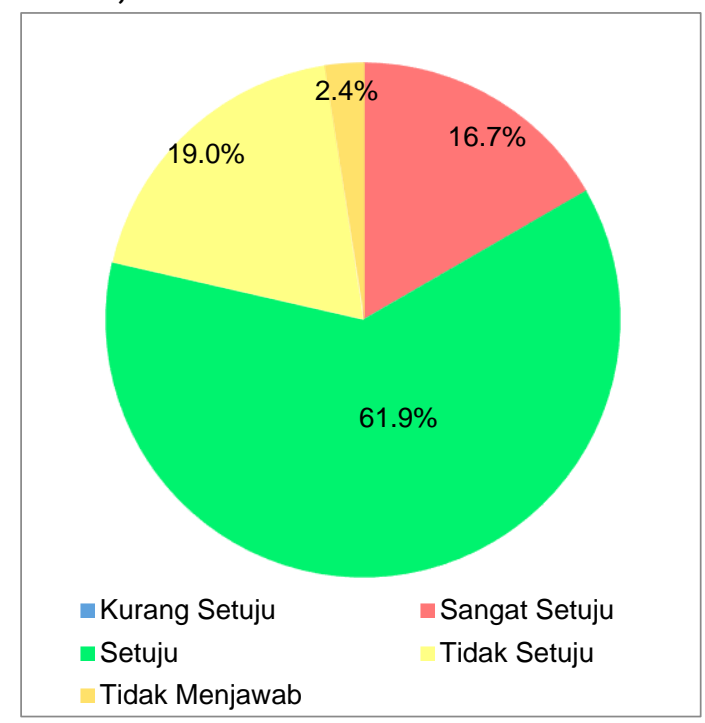

Grafik 2.c.1 
c.2. Bagaimana hubungan antar umat beragama di wilayah anda tinggal

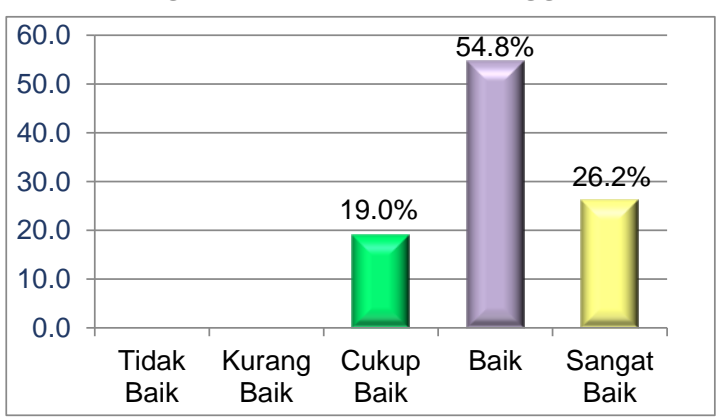

Grafik 2.c.2

\section{c. Aspek Sikap}

1) Penyuluh belum maksimal menghadirkan perubahan nyata di masyarakat dan akar rumput suasana batin yang tenteram dan rukun

a) Penyuluhan agama diperlukan untuk menghadirkan perubahan nyata di masyarakat berbangsa dan bernegara namun peran penting untuk secara aktif menciptakan suasana batin yang tentram dan rukun hingga akar rumput masih belum maksimal dan dipertanyakan

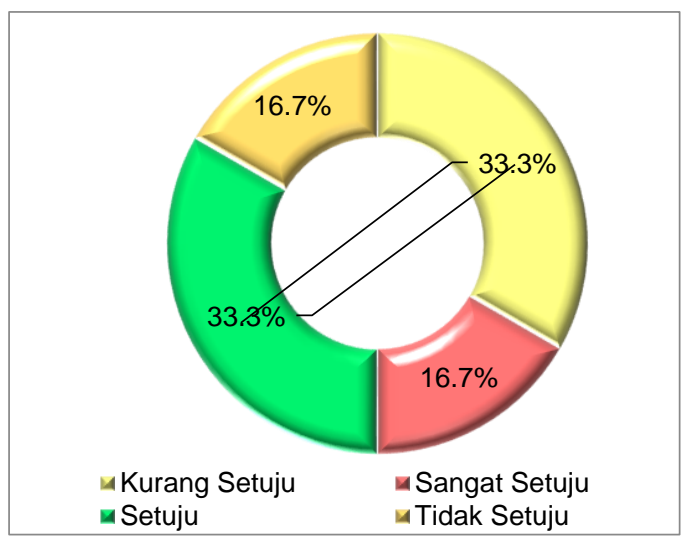

Grafik c.1)a)

b) Semakin tinggi intensitas konflik keagamaan pada sebuah komunitas umat beragama menandakan kualitas kerukunan keagamaan pada komunitas tersebut semakin rendah

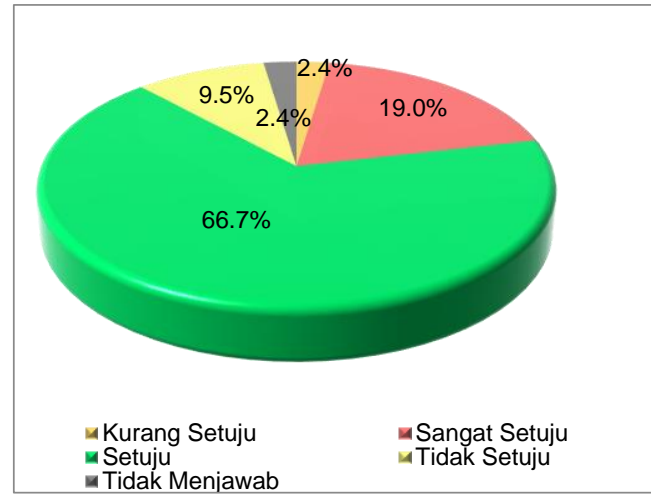

Grafik c.1)b)

2) Apakah ada kearifan lokal yang bisa menyatukan dalam konfigurasi masyarakat plural.

a) Dalam masyarakat di wilayah anda, apakah ada aturan atau pepatah (kearifan lokal) yang bisa menyatukan masyarakat meskipun berbeda agama

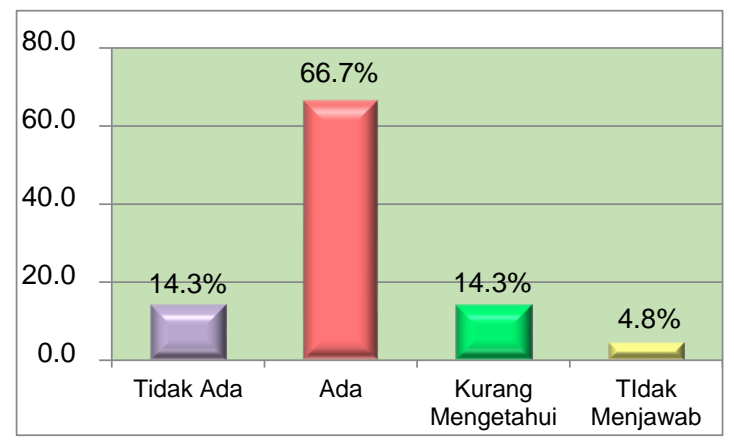

Grafik c.2)a)

\section{d. Aspek Kerjasama}

1) Kerjasama antar tokoh umat beragama sering gagal karena ego sektoral dan fanatisme agama

a) Kerjasama antara tokoh berbeda agama untuk menjaga umat beragama agar tidak terjadi konflik sangat penting namun sering gagal karena ego sektoral. 


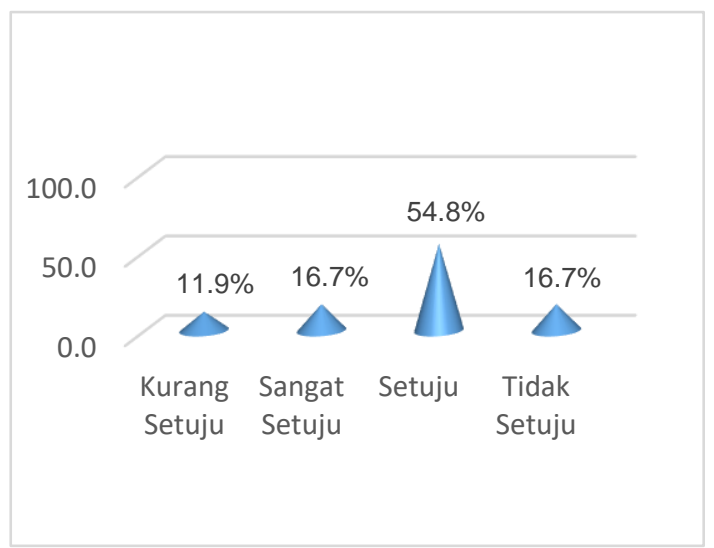

Grafik d.1)a)

b) Apakah ada kerjasama antara tokoh berbeda agama untuk menjaga umat beragama agar tidak terjadi konflik

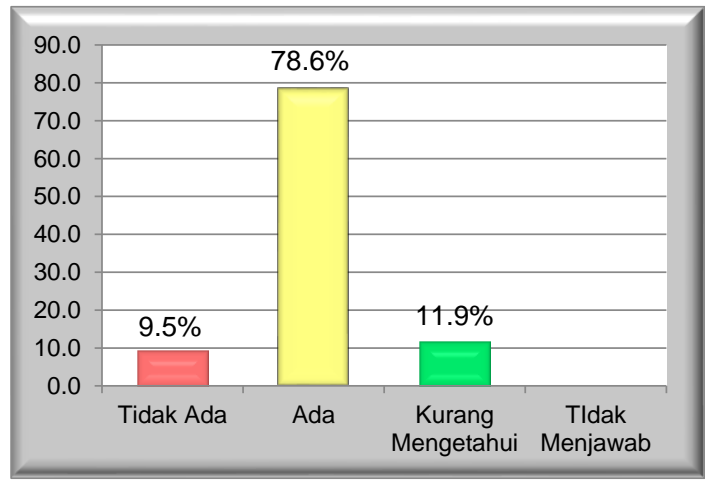

Grafik d.1)b)

\section{PENUTUP}

\section{Simpulan}

Kompetensi Penyuluh Agama dalam memelihara harmoni kerukunan sudah memiliki persepsi dan pemahaman yang benar pada ajaran agama dan norma (world view) dalam membangun wawasan tentang pluralitas dan multi etnis (multikulur). Sikap dalam berinteraksi atau relasi sosial yang proaktif ketika mengelola konflik dan mendayagunakan kearifan lokal untuk meminimalisir perbedaan menjadi kompetensi sosial yang harus selalu diasah.

Faktor Intoleransi akibat dari penafsiran teks-teks keagamaan secara literal dan radikal serta mengarah pada masyarakat yang terjebak pada truth claim, menganggap diri atau kelompoknya sendiri yang paling benar dan menyalahkan hasil penafsiran orang lain menjadi tantangan tersendiri bagi penyuluh dalam membangun hubungan sosial dengan kelompok sasaran binaan. Pada tataran ini pengayaan materi dan metode penyuluhan yang berkaitan dengan kerukunan umat beragama sangat diperlukan variasi dan aplikasi yang bersifat keteladanan.

Frekuensi bimbingan dan penyuluhan yang terkait dengan hal-hal yang di picu oleh masalah berlatar belakang agama antara lain konflik atau kekerasan antar umat beragama atau internal umat beragama karena perbedaan keyakinan atau akidah, pendirian tempat ibadah dan penggunaan simbol-simbol untuk kepentingan tertentu sehingga menimbulkan reaksi bahkan penolakan, tak jarang ada perlawanan dari kelompok lain, menyisakan masalah seperti api dalam sekam, sehingga bimbingan dan penyuluhan harus kontinu dan massif.

\section{Rekomendasi}

Pusdiklat sebagai penyelenggara Pelatihan harus memfasilitasi para Penyuluh baik PNS dan Non PNS melalui Pelatihan substantif Kerukunan Umat Beragama dan Moderasi Beragama dalam upaya peningkatan kualitas Penyuluh dan peningkatan kompetensi bimbingan Penyuluhan.

Kepada pemerintah, khususnya Kementerian Agama dan Pemerintah Daerah Provinsi DKI Jakarta selaku pemegang kebijakan, agar dapat memberi perhatian serius terhadap peningkatan Kompetensi Penyuluh sebagai ujung tombak dan garda terdepan untuk internalisasi sikap toleransi, kesetaraan dan kerjasama antar umat beragama dan intern umat beragama.

Dukungan berupa dana operasional bagi penyuluh yang memadai terutama di wilayah 3 T ( Tertinggal, Terdepan, Terluar ) dan potensial terjadi intoleran dan rawan konflik.

Perlu secara masif dan berkala diadakan Dialog Keagamaan yang mengusung tema Ketahanan bangsa dalam perspektif agamaagama lintas iman untuk mencari titik temu dan membangun kebersamaan dalam keragaman. 


\section{DAFTAR PUSTAKA}

Adi, I. (2003). Pemberdayaan, Pengembangan Masyarakat dan Intervensi Komunitas : Pengantar pada Pemikiran dan Pendekatan Praktis. Jakarta: Lembaga Penerbit Fakultas Ekonomi Universitas Indonesia.

Amin, S. M. (2008). Rekonstruksi Pemikiran Dakwah Islam. Jakarta: Amzah.

Arifin, M. (1996). Teori-teori Konseling Umum dan Agama. Jakarta: Golden Terrayon Press.

Arifin, M. (1997). Psikologi Dakwah Suatu Pengantar. Jakarta: Bumi Aksara.

Asry, M., Hakim, B., Ruhana, A., \& Khalikin, A. (2013). Masyarakat Membangun Harmoni: Resolusi Konflik dan Bina Damai Etnorelijius di Indonesia. Jakarta: Puslitbang Kehidupan Keagamaan.

Bidang Pendidikan Agama Islam pada Masyarakat dan Pemberdayaan Masjid. (2010). Pedoman dan Petunjuk Teknis Penyuluh Agama Islam Fungsional Jilid I\& II. Bandung: Kementerian Agama Kantor Wilayah Provinsi Jawa Barat.

Culp, K., McKee, R. K., \& Nestor, P. (2007, Desember). Identifying Volunteer Core Competencies : Regional Differences. Jurnal of Extension, 45(6). Retrieved September 11, 2011, from http://www.joe.org/joe/2007-december/ a3.php

Hasjmy. (1994). Dustur Dakwah Menurut Al Qur'an. Jakarta: Bulan Bintang.

Heyneman, S. P. (2005). Introduction to this special issue on organisation and social organitasion. Peabody Journal of Education, 80(4).

Hidayatulloh, M. T. (2014). Strategi Peningkatan Kompetensi Penyuluh Agama Islam di Tiga Daerah Provinsi Jawa Barat. Bogor: Sekolah Pascasarjana Institut Pertanian Bogor.

Ife, J. (2002). Community Development : Community Based Alternatives in Age of Globalisation (2 ed.). Malaysia: Longman.

Keputusan Bersama Menteri Agama RI dan Kepala Badan Kepegawaian Negara Nomor 574 tahun 1999 dan Nomor 178 tahun 1999 tentang Jabatan Fungsional Penyuluh Agama dan Angka Kreditnya. (1999).

Keputusan Menteri Agama Nomor 516 Tahun 2003 tentang Petunjuk Teknis Pelaksanaan Jabatan Fungsional Penyuluh Agama dan Angka Kreditnya. (2003).

Kurniawan, R., \& Jahi, A. (2005, September). Kompetensi Penyuluh Pertanian di Tujuh Kecamatan di Kabupaten Bekasi Jawa Barat. Jurnal Penyuluhan, 1(1).

Lawang, R. M. (2004). Kapita Sosial dalam Prespektif Sosiologi: Suatu Pengantar. Depok: Fisip UI.

Lippitt, R., Watson, J., \& Westley, B. (1958). The Dynamics of Planned Change. New York: Harcourt, Brace \& World, Inc.

Marius, J. A., Sumardjo, Slamet, M., \& Asngari, P. S. (2007, September). Pengaruh Faktor Internal dan Eksternal Penyuluh terhadap Kompetensi Penyuluh di Nusa Tenggara Timur. Jurnal Penyuluhan, 3(2).

Miles, B. M., \& Hubermen, M. (1992). Analisis Data Kualitatif Buku Sumber Tentang Metode-metode Baru. Jakarta: UIP.

Misra, R. P. (1991). The Changing Perception of Development Problems. Singapore: Maruzen Asia.

Mubarak, A. (2000). Konseling agama Teori dan Kasus. Jakarta: Bina Rena Pariwara.

Mubarak, A. (2001). Psikologi Qur'ani Suatu Pengantar. Jakarta: Bumi Aksara.

Mulyana, D. (2002). Metodologi Penelitian Kualitatif. Bandung: PT. Remaja Rosdakarya.

Namdar, R., Rada, G. P., \& Karamidehkordi, E. (2010). Professional Competencies Needed by Agricultural and Extension Program Evaluation Staff and Managers of Iranian Ministry of Agriculture. Journal of International Agricultural and Extension Education. Retrieved September 15, 2019, from http://wwww.aiaee.org/attahments/476Gholamreza\%20pezeskhkirad.pf

Nasdian, F. T. (2003). Pengembangan Masyarakat. Bogor: Departemen Ilmu- Ilmu Sosial Ekonomi Fakultas Pertanian IPB.

Omar, M. T. (2004). Islam dan Dakwah. Jakarta: Zakia Islami Press. 
Rutherford, J. (2004). Key Competencies in the New Zealand Curriculum: A Snapshot of Consultation. Retrieved September 28, 2019, from http://nzcurriculum.tki.org.nz/content/download/826/5907/file/consultsnapshot.doc

Santopolo, F. A., \& Gallaher, J. A. (1967). Perspectives on Agent Roles. Journal of Cooperative Extension. Retrieved Februari 3, 2012, from http://www.joe.org/joe/1967winter/1967-4-a3.pdf

Schmitt, R. B. (2002). Considering Sosial Cohesion in Quality of Life Assesment: Concept and Measurement. Sosial Indicator Research, 58.

Spencer, L. M., \& Spencer, S. M. (1993). Competence at Work: Model for Superior Competence Performance. New York: John Wiley \& Sns. Inc.

Swanson, B. E., Bentz, R. P., \& Sofranko, A. J. (1997). Improving Agricultural Extension. Roma: FA0.

Valera, J. B., Martinez, V. A., \& Plopino, R. F. (1987). An Introduction to Extension Delivery Systems. Manila: Island Publishing House. Inc.

Winaryanto, S., Sahirul, A., \& Yunasaf, U. (2011). Kajian Tingkat Kompetensi Profesional Penyuluh Bidang Peternakan di Kabupaten Bandung Barat. Retrieved September 28, 2018, from http://pustaka.unpad.ac.id/wp-content/uploads/2011/08/kajian-Tingkat-Kompetensi.doc 